\title{
Effects of Regular Off-farm Activities on Household Agricultural Income: Evidence from Kenya's Kerio Valley
}

\author{
https://doi.org/10.21272/sec.3(3).13-20.2019
}

\author{
Manitra A. Rakotoarisoa \\ Lead Economist, Infinite Sum Modeling LLC, USA
}

\section{Simeon Kaitibie}

Associate Professor, Lincoln University, New Zealand

\begin{abstract}
This paper contributes to clarifying the scientific debate on whether off-farm activities hurt or help agricultural income. The main purpose of this research is to estimate the impacts of rural household's participation in regular off-farm activities on agricultural income. The literature indicates that off-farm activities affect rural household's income but studies on their effect on agricultural income have remained largely inconclusive. Determining how off farm activities affect agricultural income is highly relevant for the decisions of poor rural households and policy makers to allocate resources efficiently and increase investment to combat poverty. Investigation of the effects of regular off-farm activities is carried out in the following logical sequence: we performed surveys to gather information from rural households located in the Kerio Valley in Kenya; using the matching technique, we compared agricultural income per capita between households that took part in regular off-farm activities and those that did not. Methodological tools of the research were the results of a three-year project focusing on improving rural income. The object of research is the households in Kerio Valley in Kenya because they practiced the typical mix of farm and off-farm activities in rural Kenya. The empirical results of the analysis showed at first that household's participation in regular off-farm activities had no significant effect on household agricultural income per capita. However, by splitting agricultural income into crop and livestock incomes, we found that participation in regular off-farm activities did not affect crop income per capita but it increased livestock income per capita. The results can be useful to policy makers because it shows the existence of a symbiotic association between regular off-farm activities and livestock production. The results also confirm that creating opportunities for rural households to engage in off-farm activities generates supplemental revenues, and more importantly, reliable assets.
\end{abstract}

Keywords: matching technique, agricultural income, off-farm activities.

JEL Classification: Q12, D13, C1.

Cite as: Rakotoarisoa, M.A., Kaitibie, S. (2019). Effects of Regular Off-farm Activities on Household Agricultural Income: Evidence from Kenya's Kerio Valley. SocioEconomic Challenges, 3(2), 13-20.

https://doi.org/10.21272/sec.3(3).13-20.2019.

(C) The Authors, 2019. This article is published with open access at Sumy State University.

\section{Introduction}

Off-farm activities are known for their contribution to rural households' incomes (Haggblade et al., 1989; Ranis and Stewart, 1993; Bryceson, 1996; Haddad et al., 1997; Reardon, 1997; Lanjouw and Lanjouw, 2001), but their specific and direct contribution to agricultural income in rural Africa remains little understood. Here, we define off-farm activities as paid work outside the household's own farm. In rural areas, off-farm activities in both the private sector (e.g. working at others' farm, shop-keeping, trading, driving, plumbing) and public sector (e.g. nursing, teaching) are often viewed as sources of extra income for households to pay for their expenditures unrelated to farming such as children's education, health care, and clothing. But studies such as Stampini and Davis (2008) for Vietnam and Boisvert and Chang (2006) and Fernandez-Cornejo (2007) for the US have shown that off-farm activities can directly affect agricultural activities. These studies reveal that for a typical rural household, off-farm activities may compete with on-farm activities for time and labour allocation, but they may also generate income that can be invested in agriculture. For rural Africa, the existing literature on off-farm activities focuses mostly on the diversification aspect (Barrett et al. 2000, 2001) or the 
determinants (Abdulai and Delgado, 1998; Ackah, 2013; Nagler and Naudé, 2017) of off-farm activities and often overlooks the direct link between off-farm activities and agricultural income. ${ }^{1}$ This link is what we want to investigate.

This paper seeks to estimate the effect of household participation in regular off-farm activities on agricultural (crop and livestock) income per capita for rural households in Kerio Valley, Kenya. Crop and livestock revenues per capita across households in the valley vary greatly (Kristjanson et al., 2005). Our aim is to determine whether participation in regular off-farm activities is one of the explanations of the inequality in agricultural income per capita. The analysis employs household survey data (Iiyama et al., 2008) and focuses particularly on regular (i.e. more permanent), rather than casual, off-farm activities because the data on regular activities are more reliable. Regular off-farm activities are also more relevant to a household's income stability and treasury planning. We use the matching technique to compare agricultural income per capita between households that have income from regular off-farm activities and those that do not. The matching criteria include some household characteristics (such as education attainment, gender of the head, and size of a household), technology adoption, access to market, and household assets. The estimation employs econometric method and draws conclusions on and implications for the importance of off-farm activities in rural areas.

\section{Off-farm Activities and Household and Farm Income}

There are two competing long-held views on how off-farm activities may affect on-farm, and especially agricultural, activities. On the one hand, off-farm activities, especially regular off-farm activities, generate a stable supplemental income that can be invested in technology adoption or payment of essential farm production expenses such as inputs or the delivery system. These investments will increase production and productivity for on-farm activities of the household. On the other hand, off-farm activities may not support on-farm and agriculture activities and may even take away important resources such as family labour and financial assets from on-farm activities. In this case, off-farm activities have no impact or may even hurt agricultural productivity and returns.

Following these two different views, there are two hypotheses regarding ways off-farm activities may affect the efficiency of rural-household activities. The first hypothesis is that efficiency of the rural-household activities (including farming) increases as the household participates in an off-farm activity. Economies of scope explain this hypothesis in that diversifying the activity to include both off-farm activities and on-farm activities may prove more profitable than performing one type of activity at a time. The advantage of such economies of scope comes usually from the managerial saving and from the spillover effects of the skills acquired in either one or both of these two types of activities. A farm employee acquiring skills in, say, using integrated pest management can apply the same technique at her own plots at home. Similarly, her practices and successes in doing so at home strengthen her skills and raise her productivity further in her employer's farm.

The second hypothesis opposes the first in asserting that household and farm efficiency decrease with offfarm income. This second argument can be understood through the idea that some types of off-farm activities remove scarce resources such as skilled labour from farming (labour-intensive cropping); the price of the moving resource will then rise, and this reduces profit, especially when neither physical, nor human, nor financial capital could substitute for it. ${ }^{2}$ We test these two hypotheses by using information on rural households in Kerio Valley, Kenya.

\section{The Method}

We compare the agricultural income per capita of households that are engaged in one or more regular offfarm activities with the agricultural income per capita of those who are not. We employ the matching technique (Dehejia and Wahba, 1999; Abadie et al., 2001; Imbens, 2003; Todd and Wolpin, 2010) whose advantage here is to determine how the participation in regular off-farm activities affects agriculture activities, rather than to explain why household members participate in regular off-farm activities. In the absence of historical data on participation in off-farm activity and in the absence of information on the 'before' and 'after' conditions of participation for each household, the matching technique is likely more useful than other methods.

\footnotetext{
${ }^{1}$ An exception is Evans and Ngau (1991); still it focuses only on the role of non-farm activities on farm productivity. Likewise, Babatunde and Qaim (2010) focused on off-farm activities' link to food security and nutrition.

${ }^{2}$ See findings and discussions in Kumbhakar et al. (1989) and Goodwin and Mishra (2004).
} 
For each household, the matching technique compares the observed outcome to an estimated outcome. The technique computes an estimate of agricultural income per capita for a non-participating (or participating) household had it (or had it not) participated in any regular off-farm activity. It does so by averaging over the values of agricultural income per capita of the participating (or non-participating) households which are the most 'similar' to each of the non-participating (or participating) households. The 'similarity' criteria, also called the 'matching' variables are specific household characteristics (such as size, asset owned, and education attainment) chosen arbitrarily before the analysis. The average of the difference between the observed and the estimated agricultural income per capita should reflect how much the participation in regular off-farm activity affects agricultural income per capita.

Following standard notations, we assign a dummy variable $W_{\mathrm{i}}=0,1$ to indicate whether or not a household $i$ participates in a regular off-farm activity and $Y_{i}\left(W_{i}\right)$ as the outcome for individual household $i$. The outcomes $Y_{i}(1)$ and $Y_{i}(0)$ represents, respectively, the outcomes when $i$ participates and when $i$ does not participate in any regular off-farm activities. Ideally, an estimate of the average effect would be just $\mathrm{E}=(1 / \mathrm{N}) \Sigma_{\mathrm{i}}\left(Y_{i}(1)-\right.$ $\left.Y_{i}(0)\right)$. But in this paper the nature of the data is such that each observed household $i$ has only one observed outcome (i.e., the household either participates or it does not), so we need to use an estimate of the missing outcome to make the comparison. Such an estimate is constructed in the matching technique as the simple average of the outcomes of households that share similar (or closest) characteristics of the household $i$ (Abadie et al., 2001).

Formally the matching estimator for the average treatment effect is $\tau=\frac{1}{N} \sum_{i=1}^{N}\left(\hat{Y}_{i}(1)-\hat{Y}_{i}(0)\right)$.

where the matching estimates $\hat{Y}_{i}(0)$ and $\hat{Y}_{i}(1)$ are defined as follows:

$\hat{Y}_{i}(0)= \begin{cases}Y_{i}(0) & \text { if } W_{\mathrm{i}}=0 \\ & \\ \left(1 / M_{i}\right) \sum_{i \in M_{i}} Y_{i} & \text { if } W_{\mathrm{i}}=1\end{cases}$

$\hat{Y}_{i}(1)= \begin{cases}\left(1 / M_{i}\right) \sum_{i \in M_{i}} Y_{i} & \text { if } W_{\mathrm{i}}=0 \\ Y_{i}(1) & \text { if } W_{\mathrm{i}}=1\end{cases}$

where $Y_{i}$ s are the outcomes, $W_{i}=1,0$ indicates participation or non-participation, and $M_{i}$ is the number of the households that have the same or the closest characteristics to household $i .^{3}$

Basic assumptions: unconfoundedness and identifiability.

Two basic assumptions permit the use of the matching technique. ${ }^{4}$ The first is the so-called 'unconfoundedness' assumption, which ensures that for households having the same characteristics, the participation in regular off-farm income activities is random and independent of the agricultural revenue. The nature of the data used in this study lends support to this assumption because many households have no prior knowledge of whether or not their participation in off-farm activities affects agricultural income positively. For the rural households in our sample, the primary goal in acquiring off-farm income is often to stabilize income stream

\footnotetext{
${ }^{3}$ See details in Abadie et al. (2001).

${ }^{4}$ See Imbens (2003) for ample explanations.
} 
to support the household's overall expenditures or savings and not necessarily expenditures for agriculture production. The second assumption, which is also realistic for our data analysis, is the 'identifiability' assumption, which ensures that there is at least one household that is not involved in any regular off-farm activity in order to perform the matching with those that are involved.

\section{The Data}

The dataset came from a 2006 survey on 177 households in villages in the Kerio Valley, Kenya (Iiyama et al., 2008). The villagers are mostly crop growers and livestock keepers, and the data show that agricultural production provided about half of household income that year. The data also indicate that 53 out of 177 households in the sample are involved in at least one regular (i.e., permanent) off-farm activity. Many more households are engaged in casual off-farm activities, but these activities are temporary and do not provide stable income on a regular basis over a year. As stated earlier, our estimation focuses only on the regular off-farm activities. The types of regular off-farm activities that household members engage in include driving, teaching, plumbing, working at another farm, and trading crops and livestock.

\section{The matching variables}

Great care was taken in choosing the matching variables because the aim was to isolate the effects of the regular off-farm activity from the effects of, say, educational level, technology adoption, fertilizer use, and assets. Here we retained the following as matching variables:

$>$ household characteristics: number of years of education of the head of household, age of the head of household, gender of the head of household; household (family) size;

$>$ agricultural assets: number of acres of land cultivated, total number of livestock unit equivalent (tlu);

$>$ other assest: possession of radio;

$>$ technology adoption: application of mulching technique; and

$>$ market access: amount of time spent to reach the agricultural market.

Table 1 summarizes some key information about Kerio valley's household characteristics including the matching variables described above. Agricultural income per capita, the outcome variable in this paper, is on average about 11.5 thousand Kenya Shillings (or about 65 USD). However, a member of a household participating in one or more regular off-farm activities earns about 7 thousand KSh. more (for a total of about 100 USD) than a member of a household that does not participate in a regular off-farm activity. On average and in comparison to a non-participant household, a participant household tends to have a more educated and younger head of household and has slightly more members. A regular off-farm activity household also uses more acreage, has more livestock units, and has greater access to markets than its counterpart. Moreover, about half of the household participants in regular off-farm activity adopted the mulching technology, whereas less than a fifth of non-participants did. However, many of these variables, especially the income variables, have large standard deviations (far greater than the mean), indicating that these simple averages may not be the best estimates for sake of comparison.

Table 1. Statistical Average of Household Characteristics, Kerio Valley

\begin{tabular}{|c|c|c|c|}
\hline & Overall & $\begin{array}{l}\text { Participants in regular off- } \\
\text { farm activities }\end{array}$ & $\begin{array}{c}\text { Non-Participants in regular off-farm } \\
\text { activities }\end{array}$ \\
\hline \multicolumn{4}{|l|}{ Variables } \\
\hline $\begin{array}{l}\text { Gross income per capita (thou- } \\
\text { sand K. Shillings) }\end{array}$ & $\begin{array}{l}25.65 \\
(35.25)\end{array}$ & $\begin{array}{l}45.35 \\
(50.29)\end{array}$ & $\begin{array}{l}17.22 \\
(21.69)\end{array}$ \\
\hline $\begin{array}{l}\text { Ratio of agricultural income to to- } \\
\text { tal household income }\end{array}$ & 0.45 & 0.38 & 0.48 \\
\hline $\begin{array}{l}\text { Agricultural income per capita } \\
\text { (thousand K. Shillings) }\end{array}$ & $\begin{array}{c}11.54 \\
(18.33)\end{array}$ & $\begin{array}{c}16.43 \\
(21.23)\end{array}$ & $\begin{array}{c}9.45 \\
(16.64)\end{array}$ \\
\hline $\begin{array}{l}\text { Crop income per capita (thousand } \\
\text { of K. Shillings) }\end{array}$ & $\begin{array}{c}6.88 \\
(14.32)\end{array}$ & $\begin{array}{c}8.60 \\
(13.41)\end{array}$ & $\begin{array}{c}6.16 \\
(14.68)\end{array}$ \\
\hline $\begin{array}{l}\text { Livestock income per capita } \\
\text { (thousand K. Shillings) }\end{array}$ & $\begin{array}{c}4.66 \\
(9.40)\end{array}$ & $\begin{array}{c}7.84 \\
(12.92)\end{array}$ & $\begin{array}{c}3.30 \\
(7.04)\end{array}$ \\
\hline $\begin{array}{l}\text { Number of years of education of } \\
\text { family head }\end{array}$ & $\begin{array}{c}6.25 \\
(4.65)\end{array}$ & $\begin{array}{l}10.26 \\
(4.23)\end{array}$ & $\begin{array}{c}4.53 \\
(3.66)\end{array}$ \\
\hline
\end{tabular}


Table 1 (cont.). Statistical Average of Household Characteristics, Kerio Valley

\begin{tabular}{|l|c|c|c|}
\hline & Overall & $\begin{array}{c}\text { Participants in regular off- } \\
\text { farm activities }\end{array}$ & $\begin{array}{c}\text { Non-Participants in regular off-farm } \\
\text { activities }\end{array}$ \\
\hline Variables & \multicolumn{2}{|c|}{} & $\begin{array}{c}50.58 \\
(18.11)\end{array}$ \\
\hline Age of head of household & $\begin{array}{c}46.85 \\
(17.63)\end{array}$ & $\begin{array}{c}38.11 \\
(12.89)\end{array}$ & $\begin{array}{c}4 \\
(2.49)\end{array}$ \\
\hline Household size & $\begin{array}{c}4.27 \\
(2.48)\end{array}$ & $\begin{array}{c}4.89 \\
(2.34)\end{array}$ & 6.05 \\
\hline Land use (acres) per household & $\begin{array}{c}7.55 \\
(18.12)\end{array}$ & $\begin{array}{c}11.07 \\
(28.95)\end{array}$ \\
\hline $\begin{array}{l}\text { Number of livestock unit equiva- } \\
\text { lent (tlu) per household }\end{array}$ & $\begin{array}{c}5.14 \\
(7.45)\end{array}$ & $\begin{array}{c}6.61 \\
(8.07)\end{array}$ & $\begin{array}{c}4.52 \\
(7.10)\end{array}$ \\
\hline Elapsed time to market (minutes) & $\begin{array}{c}21.67 \\
(16.23)\end{array}$ & $\begin{array}{c}14.04 \\
(10.97)\end{array}$ & $(17.04)$ \\
\hline $\begin{array}{l}\text { Number of households applying } \\
\text { mulching technique }\end{array}$ & 49 & 26 & 23 \\
\hline $\begin{array}{l}\text { Number of household under ob- } \\
\text { servation }\end{array}$ & 177 & 53 & 124 \\
\hline
\end{tabular}

Notes: Standard deviations are in parentheses.

\section{Results of the Estimation}

We compute and compare the estimates of the sample average treatment effects (SATE), the sample average of the treated (SATT) and the sample average of the control (SATC). As their names indicate, SATE is obtained by using the matching technique and taking the average estimates of the effects on all observations, whereas SATT and SATC are obtained by using the technique on only those households that participated in regular off-farm activity and only those which did not participate, respectively.

Table 2. Effects of the participation in regular off-farm activities on household per capita income using matching technique (in thousand Kenya Shillings)

\begin{tabular}{|c|c|c|c|}
\hline & $\begin{array}{l}\text { Average Treatment } \\
\text { Effect }\end{array}$ & $\begin{array}{c}\text { Average Treatment Effect of } \\
\text { the Treated }\end{array}$ & $\begin{array}{c}\text { Average Treatment Effect of } \\
\text { the Control }\end{array}$ \\
\hline \multicolumn{4}{|l|}{ Effects on: } \\
\hline Total agricultural income per capita & $\begin{array}{c}2.59 \\
(0.67) \\
\end{array}$ & $\begin{array}{c}0.31 \\
(0.06)\end{array}$ & $\begin{array}{c}3.55 \\
(0.84) \\
\end{array}$ \\
\hline Crop income per capita & $\begin{array}{l}-1.42 \\
(-0.43)\end{array}$ & $\begin{array}{c}-3.2 \\
(-0.73)\end{array}$ & $\begin{array}{c}-0.7 \\
(-0.19)\end{array}$ \\
\hline Livestock income per capita & $\begin{array}{l}4.05 * * \\
(2.58)\end{array}$ & $\begin{array}{l}3.55^{*} \\
(1.78)\end{array}$ & $\begin{array}{l}4.26^{*} \\
(2.50)\end{array}$ \\
\hline $\mathrm{N}=177$ & & & \\
\hline
\end{tabular}

Note: Levels of significance: $* * 1 \%$ and $* 5 \%$. The $\mathrm{z}$-values are in parenthesis. These estimates are already corrected for bias that arises from the discrepancies in the values of matching variables within the matches ${ }^{5}$.

Table 2 shows and compares the results of the computation of three estimates of treatment. Results first show that participation in a regular off-farm activity is not associated with any increase in total agricultural (crop and livestock combined) income per person for households sharing about the same attributes (assets, education, etc...). Estimation of the sample average treatment effect (SATE) indicates that the total agricultural income per capita of households whose members participate in one or more regular off-farm activities is not statistically different from that of non-participants. An explanation is that income from regular off-farm activities may have been mostly spent on households' needs other than farm expenditures. Another explanation is that there is an increase in the purchasing power of the rural poor that helped increase technical efficiency in agricultural production, such that off-farm activities complement on-farm activities; but this increase in technical efficiency may have been erased by a rise in farm production costs (especially labour costs) as household members devote more time and resources to off-farm activities. This is for instance the case when

\footnotetext{
${ }^{5}$ See Abadie et al. (2001), Abadie and Imbens (2002).
} 
households have to hire outsiders at a higher cost to tend their animals or labour the soil because their own members pursue jobs outside the farm or the village.

The results above are based on the aggregate agricultural income; because aggregate figure may not tell much about the effects of the regular off-farm activities on its components, a further step toward disaggregating the income data is needed. When we split agricultural income into crop and livestock incomes, the results on all three estimates SATE, SATT, and SATC reveal that, whereas off-farm activity's association with crop income is muted or inexistent, its association with livestock income is statistically significant. The last column of Table 2 shows that livestock income per capita in a household whose members engage in regular off-farm activity is about 4 thousand shillings (about 60 USD) higher than that of non-participating households. Such an amount is important: it is about three times larger than the minimum overall income per capita of the surveyed households in Kerio Valley. This association between livestock income per capita and off-farm activity contradicts the view (e.g. Nehring, Fernandez-Cornejo, and Bankers, 2005) that the opportunity cost of labour would be higher in livestock than in crop production, which implies that livestock income would be slashed more severely than crop income when households engage in off-farm activities.

Nevertheless, the positive correlation between off-farm activities and livestock income per capita is in line with more recent literature. As an example, Stampini and Davis (2008) have found similar evidence indicating that off-farm activities relax farm-credit constraints and pay for livestock inputs. Indeed, one explanation is that the surveyed area of Kerio Valley is a livestock area where people often use the extra income to invest directly in livestock production. ${ }^{6}$ Another explanation of this positive association is that the reallocation of time (labour) from livestock keeping to off-farm activities where returns are higher may have improved household efficiency, and the increased income coming from such an increased efficiency is invested in livestock production. For the households in the Kerio Valley, crop production attracted lesser investment perhaps because of many constraints such as land tenure, land use, and crop price instability, whereas livestock could be seen as an expandable and safer asset for saving and especially for relatively high returns.

\section{Conclusion and discussion}

Off-farm activities are linked to rural households' other activities but studying their effects on farm activities and agricultural income in rural Africa has been overlooked. Because competing theories leave ambiguous prediction on the effects of off-farm activities on agricultural income, we relied on empirical evidence to provide an answer. Using survey data from villages in the Kerio Valley of Kenya, we investigated the relation between regular off-farm activities and household agricultural income. We employed the matching technique where per capita agricultural income of household engaged in regular off-farm activities is compared to that of non-participating households having similar characteristics.

Results showed that participation in regular off-farm activities has no effects on overall agricultural income per capita. However, by splitting agricultural income into crop and livestock incomes, we discovered that while participation in regular off-farm activities does not affect per capita crop income, it affects per capita livestock income positively. This effect on the household's livestock income can be explained by the importance of livestock as an asset for saving and investment in a livestock area such as the Kerio Valley.

These findings based on survey data in the Kerio Valley would have been strengthened if the sample were larger or if more rural sites were included in the survey. The evidence is only from this particular survey and does not necessarily represent the effects of off-farm activities in other areas. Likewise, the lack of time series data constrained our analysis. Great care was taken to limit possible measurement errors during the survey but remaining errors inherent to respondents' estimation of monetary values may still persist and could bias the parameter estimates. However, the results strongly indicate that investigating the role of off-farm activities provides an important leeway to increase farm activities to further raise farm rural household income.

The findings imply that besides their primary goal of smoothing household income, especially of covering households' expenditures (such as children's schooling and medical care fees), regular off-farm activities support or at least complement agricultural production. The symbiotic association between off-farm activities and livestock production in the Kerio Valley confirms that livestock production represents an asset worth

${ }^{6}$ See Ilyiama et al. (2008). 
investing in. Creating the opportunities ${ }^{7}$ for rural households to engage in off-farm activities, for instance by increasing education (Yang, 1997) or developing rural information network (VanWey and Vithayathil, 2013) will possibly generate supplemental revenues, and more important, reliable assets to reduce poverty.

\section{References}

1. Abadie, A., D. Drukker, J.L. Herr, and G. W. Imbens (2001). Implementing Matching Estimators for Average Treatment Effects in Stata. The Stata Journal, 1, 1-18.

2. Abadie A. and G. Imbens (2002). Simple and Bias-Corrected Matching Estimators. Technical Report. Department of Economics, UC Berkeley. Avalable at: http://emlab.berkeley.edu/users/imbens/.

3. Abdulai A, C.L. Delgado (1998). Determinants of Non-farm Earnings of Farm-Based Husbands and Wives in Northern Ghana. American Journal of Agricultural Economics, 81, 117-130.

4. Ackah C. (2013). Non-farm Employment and Income in Rural Ghana. Journal of International Development, 25, 325-339.

5. Babatunde R., M. Qaim (2010). Impact of Off-farm Income on Food Security and Nutrition in Nigeria. Food Policy, 35(4), 303-311.

6. Barrett C., M. Bezuneh, D. Clay, And T. Reardon (2000). Heterogeneity Constraints, Incentives, and Income Diversification Strategies in Rural Africa. Report to USAID/BASIS CRSP, Cornell University and Michigan State University, August.

7. Barrett C., T. Reardon, P. Webb (2001). Nonfarm Income Diversification and Household Livelihood Strategies in Rural Africa: Concepts, Dynamics, and Policy Implications. Food Policy, 26(4), 315-331.

8. Boisvert, R.N. and H. Chang (2006). Does Participation in the Conservation Reserve Program and OffFarm Work Affect the Level and Distribution of Farm Household Incomes? Selected Paper prepared for presentation at the American Agricultural Economic Association Annual Meetings, Long Beach, CA, July 23-26, 2006.

9. Bryceson D. (1996). Deagrarianization and rural employment in sub-Saharan Africa: a sectoral perspective. World Development, 24(1), 97-111.

10. Dehejia R. H. and S. Wahba (1999). Causal Effects in Nonexperimental Studies: Reevaluating the Evaluation of Training Programs. Journal of the American Statistical Association, 94, 1053-1062.

11. El-Osta H, A. Mishra, and M. Morehart (2008). Off-Farm Labor Participation Decisions of Married Farm Couples and the Role of Government Payments. Review of Agricultural Economics, 30, 311-332.

12. Evans, H. and P. Ngau (1991). Rural-Urban Relations, Household Income Diversification and Agricultural Productivity. Development and Change, 22, 519-545.

13. Fernandez-Cornejo J. (2007). Off-farm Income, Technology Adoption, and Farm Economic Performance. Economic Research Report No.36. United States Department of Agriculture. Economic Research Service.

14. Goodwin, B.K. and A.K. Mishra (2004). Farming Efficiency and the Determinants of Multiple Job Holding by Farm Operators. American Journal of Agricultural Economics, 86, 722-729.

15. Haddad L., J. Hoddinott, H. Alderman (1997). Intrahousehold Resource Allocation in Developing Countries. Baltimore, MD \& London: John Hopkins University Press.

16. Haggblade S., Hazell P., Brown J. (1989). Farm-non-farm Linkages in Rural sub-Saharan Africa. World Development, 17, 1173-1201.

17. Haggblade S., Hazell P., Reardon T. (2010). The Rural Non-farm Economy: Prospects for Growth and Poverty Reduction. World Development, 38, 1429-1441.

18. Iiyama, M., P. Kariuki, P. Kristjanson, S. Kaitibie, and J. Maitima (2008). Livelihood Diversification Strategies, Incomes, and Soil Management Strategies: A Case Study from Kerio Valley, Kenya. Journal of International Development, 20, 380-397.

19. Imbens, G. (2003). Semiparametric Estimation of Average Treatment Effects under Exogeneity: A Review. Tech. rep., Department of Economics, UC Berkeley. http://emlab.berkeley.edu/users/imbens/.

20. Kristjanson P. M. Radney, I. Baltenweck, J. Ogutu, A. Notenbaert (2005). Livelihood Mapping and Poverty Correlates at a Meso-Level in Kenya. Food Policy, 30, 568-583.

21. Kumbhakar, S.C., B. Biswas, and D. Von Bailey (1989). A Study of Economic Efficiency of Utah Dairy Farmers: A System Approach. The Review of Economics and Statistics, 71(4), 595-604.

\footnotetext{
${ }^{7}$ El-Osta et al. (2008) discusses the role of government payments in decision to take part in off-farm activities. Haggblade et al. (2010) analyzes how transform non-farm activities into an important tool to reduce rural poverty.
} 
22. Lanjouw J., P. Lanjouw (2001). The rural non-farm sector: issues and evidence from developing countries. Agricultural Economics, 26, 1-23.

23. Nagler P. and Naudé W. (2017). Non-farm Entrepreneurship in Rural Sub-Saharan Africa: New Empirical Evidence. Food Policy, 67, 175-191.

24. Nehring, R., J. Fernandez-Cornejo, and D. Banker (2005). Off-Farm Labor and the Structure of US Agriculture: The case of Corn/Soybean Farms. Applied Economics, 37, 633-649.

25. Ranis G., F. Stewart (1993). Rural Nonagricultural Activities in Development: Theory and Application. Journal of Development Economics, 40, 75-101.

26. Reardon T. (1997). Using Evidence of Household Income Diversification to Inform Study of the Rural Nonfarm Labor Marker in Africa. World Development, 25, 735-747.

27. Stampini M. and B. Davis (2008). Does Off-Farm Labor Relax Farmer's Credit Constraints? Evidence from Longitudinal Data for Vietnam. IZA (Institute for the Study of Labor). Discussion Paper No. 3403.

28. Todd, P. E. and K. I. Wolpin (2010). Ex-Ante Evaluation of Social Programs. Annales d'Économie et de Statistique, no. 91.

29. VanWey L. and T. Vithayathil (2013). Off-farm Work among Rural Households: A Case Study in the Brazilian Amazon. Rural Sociology, 78(1), 29-50.

30. Yang D.T. (1997). Education and Off-Farm Work. Economic Development and Cultural Change, 45, 613-632. 